\title{
INWENTARZ KOŚCIOLA PARAFIALNEGO W KIWATYCZACH Z 1853 ROKU
}

Miejscowość kresowa Kiwatycze, dawne dobra w powiecie prużańskim, oddalona jest o 35 kilometrów od Prużan. Należała do Mierzejewskiego, od którego przeszła po kądzieli w ręce Laskowskich. Katolicki kościół parafialny pw. Świętych Apostołów Piotra i Pawła, drewniany, zbudowany został w 1610 roku. Jego fundatorami byli Mikołaj i Zofia Pac ${ }^{1}$. W czasach I Rzeczypospolitej parafia kiwatycka należała do diecezji łuckiej, w dekanacie Szereszów, w województwie brzeskolitewskim, w archidiakonacie Brześć Litewski. Podobnie jak 14 innych parafii tego archidiakonatu (na 125 ogółem), Kiwatycze posiadały patronat możnowładców². W latach 1699-1850 istniał tu klasztor karmelitów trzewiczkowych. Po drugim i trzecim rozbiorze Polski (1793-1795) terytorium diecezji łuckiej znalazło się we wszystkich trzech zaborach. Tak rozparcelowana diecezja przeszła

* Ks. Waldemar W. Żurek - dr hab. historii Kościoła, dyrektor Ośrodka Archiwów Bibliotek i Muzeów Kościelnych KUL.

${ }^{1}$ Pac Mikołaj (zm. 1595), herbu Gozdawa, syn Dominika, kasztelana smoleńskiego i posła na sejm. Ożeniony z Zofią, córką Sapiehy Bohdana na Boćkach herbu Lis (zm. 1593), wojewody brzeskiego, wdową po Janie Hercyku (herbu Lubicz), starosty wiesiołowskiego. Zofia pochodziła z rodziny prawosławnej, po zmianie wyznania na rzymskokatolickie przyjęła imię Agata. Zmarła po 1628 roku. Por. Herbarz Szlachty Polskiej, opr. S. Uruski, t. 13, Warszawa 1916, s. 158; H. Lulewicz, Sapieha Bohdan, PSB, t. 34, s. 594-596; J. Wiśniewski, Pac Dominik h. Gozdawa, PSB, t. 24, s. 695 .

${ }^{2}$ Patronat - prawa nadawane przez Kościół w stosunku do beneficjum i kościoła. Do najważniejszych należało prawo prezenty biskupowi kandydata na objęcie beneficjum kościelnego. Patronem mogła być osoba duchowna, świecka, a nawet niekatolik. Patronat mógł być mieszany: duchowny, świecki lub osoby innego wyznania. Beneficja kościelne i kościoły parafialne nadawane były ich fundatorom przez biskupów. Właściciele miejscowości kościelnych jako spadkobiercy tych fundatorów byli patronami kościołów parafialnych posiadających beneficja. Kościoły w Rzeczypospolitej posiadały patronaty: szlachecki, duchowny, królewski, książęcy, mieszczański, Uniwersytetu Jagiellońskiego i cesarski (na Śląsku). S. Litak, Kościół taciński w Rzeczypospolitej około 1772 roku, Lublin 1996, s. 78-79, 386; L. Królik, Organizacja diecezji tuckiej i brzeskiej od XVI do XVII wieku, Lublin 1983, s. 281, 286. 
najcięższy kryzys w zaborze rosyjskim, łącznie z czasowym zniesieniem biskupstwa - od 27 IX 1795 do 8 V 1798 roku. Po jego przywróceniu ukazem cara Pawła I delegat apostolski Wawrzyniec Litta, dekretem De apostolica potestatis plenitudine z 8 VIII 1798, wyznaczył nowe granice biskupstwa. Na skutek tych zmian z diecezji łuckiej przeszło do biskupstwa wileńskiego około 30 parafii z trzech dekanatów: Brześć Litewski, Prużana i Kobryń. Od tego czasu parafia Kiwatycze należała do dekanatu prużańskiego w diecezji wileńskiej. Na terenie parafii funkcjonowały kaplice w Sieliszczu, Wieżkach i Równem. Według uposażenia władz państwowych parafia została zaklasyfikowana do V klasy3. W 1798 roku od uderzenia pioruna spalił się kościół parafialny. Na jego miejsce został przeniesiony kościół z Olizarowszczyzny w 1845 roku. W 1866 roku parafia została skasowana, a świątynia do 1890 roku służyła jako cerkiew prawosławna. W czasie I wojny światowej kościół spłoną. W 1917 roku nastąpiło odrodzenie parafii, a parafianie odbudowali drewnianą świątynię. Na mocy bulli papieża Piusa XI Vixdum Poloniae unitas z 28 X 1925 roku została ustanowiona diecezja pińska. W jej skład weszła część diecezji mińskiej, która znalazła się w granicach państwa polskiego po traktacie ryskim (18 III 1921) oraz 6 dekanatów z diecezji wileńskiej: bielski, brzeski, drohiczyński, kobryński, brański i prużański. Odtąd parafia Kiwatycze należała do diecezji pińskiej. W 1942 roku kościół został zabrany przez komunistów. Do dziś zachowała się dzwonnica i stary cmentarz katolicki. Obecnie miejscowość znajduje się w granicach na Białorusi, w obwodzie brzeskim, i nosi nazwę Czyżewszczyzna (Czerewszczyżna) ${ }^{4}$.

${ }^{3}$ Ukazem carskim z 1 I 1843 roku wszystkie biskupstwa w cesarstwie rosyjskim zostały podzielone na trzy klasy, od których uzależniono wysokość uposażenia biskupa ordynariusza, konsystorza i członków kapituły. Uposażenie niższego duchowieństwa diecezjalnego regulował ukaz z 15 XII 1843 roku, na mocy którego duchowieństwu wyznaczono pensję ze skarbu, w zamian za zabrany majątek. Ten ukaz podzielił parafie na pięć klas, stosownie do zajmowanego obszaru i liczby wiernych i w każdej klasie wyznaczył proboszczowi pensję etatową w wysokości: 600, 500, 400, 275 lub 235 rubli rocznie. Dodatkowo każdemu pozostawiono niewielki areał gruntów rolnych i łąk. Tam gdzie grunt nie został nadany, lub nadano go w mniejszej ilości, wypłacano ze skarbu specjalny zasiłek. Fundusze zostały utworzone w pierwszej połowie XIX wieku i miały służyć zaspokajaniu potrzeb Kościoła katolickiego w imperium rosyjskim. Zarządzało nimi Rzymskokatolickie Kolegium Duchowne w Petersburgu. Dziekani pobierali 5\% od pensji proboszczowskiej. B. Kumor, Granice metropolii i diecezji polskich (968-1939) C.d., „Archiwa Biblioteki i Muzea Kościelne”, 20 (1970), s. 294; Stownik geograficzny Królestwa Polskiego, t. 4, Warszawa 1883, s. 117; F. Sznarbachowski, Początek i dzieje Rzymsko-Katolickiej Diecezji Łucko-Żytomierskiej, obecnie Łuckiej, w zarysie, Warszawa 1926, s. 237-238.

${ }^{4}$ J. Kurczewski, Biskupstwo wileńskie, Wilno 1912, s. 235. 


$$
* * *
$$

\section{Opis rękopisu inwentarza}

Rękopis: Inwentarz kościoła parafialnego w Kiwatyczach, pochodzący z Archiwum Parafii Kiwatycze (sygn. III/I) jest rejestrem stanu kościoła parafialnego, sporządzonym na okoliczność objęcia parafii przez księdza Tomasza Lenczewskiego w październiku 1853 roku. Obecnie rękopis znajduje się w Archiwum Diecezjalnym w Drohiczynie, zespół: Archiwum Parafii Kiwatycze, Sygn. III/I.

Dokument o wymiarach: $355 \mathrm{~mm}$ x $225 \mathrm{~mm}$ ma formę składki - trzech kart zszytych nićmi w miejscu złożenia, dodatkowo dokument obejmują dwie karty sklejone w miejscu złożenia, przy czym pierwsza stanowi kartę tytułową. Dokument jest foliowany, oprócz ostatniej, doklejonej karty.

Rękopis jest napisany brunatnym atramentem na papierze ze ścieru drzewnego, karta ósma jest z papieru żeberkowego.

Stan zachowania rękopisu jest ogólnie dobry. Karty są czyste, lekko zagniecione; lekkie ich uszkodzenie występuje tylko krawędziach. Zszycie składki jest poluzowane.

Na rewersie karty siódmej widnieje lekko wykruszona, lakowa pieczęć, odciśnięta na trójkolorowym, wełnianym sznurku. W dolnej części dokumentu widoczne są małe otwory, przez które pierwotnie przeprowadzone były sznurki pieczęci.

$\mathrm{Na}$ karcie tytułowej widnieje naklejka sygnaturowa (pismo maszynowe), umieszczona przy wewnętrznej krawędzi dokumentu.

\section{Nota edytorska}

Przy wydawaniu tekstu starano się zastosować zasady edytorskie podane w Instrukcji wydawniczej dla źródet historycznych od XVI do połowy XIX wieku, red. K. Lepszy, Wrocław 1953 oraz J. Glinka, Instrukcja wydawnicza dla nowożytnych źródeł dziejowych, Warszawa 1949. W szczególności dostosowano tekst w miarę możliwości do współczesnych zasad ortograficznych przy jednoczesnym dążeniu do zachowaniu dialektalnej i historycznej specyfiki występującego w nim zasobu leksykalnego. Uzupełnienia i uwagi wydawcy zostały ujęte w nawiasy kwadratowe.

[k. 2] Inwentarz funduszu kościoła parafialnego kiwatyckiego przy objęciu probostwa W. S. księdzu Tomaszowi Lenczewskiemu proboszczowi w miesiącu oktobrze dnia 1853 roku sporządzony

\section{Kościól parafialny klassy}

Kościół parafialny kiwaczycki w majętności Kiwaczycach w powiecie prużańskim, z drzewa w roku 1610 pod tytułem Ś.Ś. Apostołów Piotra i Pawła przez Mikołaja i Zofię z Sapiehów Paców postawiony - lecz w roku 1798 przez piorunowy ogień ze wszystkimi ozdobami został spaliony [sic!], na miejscu którego w tymże roku 1798 wystawiony został kościółek z dzwonicy [sic!] z dodaniem 
dalszego materiału, a teraz, w roku 1844 , na nowo z drzewa zbudowany na podmurowaniu, mający długości arszynów ${ }^{5} 28$, a szerokości 16, wysokości zaś 9 . Facjata ${ }^{6}$ tego kościoła o dwóch kopułach obmaliowanych czerwono, a wierzchy tychże kopuł zielioną, cały kościół okozchowany [?] tarcicami ${ }^{7}$ sosnowemi pod hebel, lisicami ${ }^{8}$ czterma podłużne ściany umocowane, a każda lisica umocowana trzema sworzniami ${ }^{9}$ i mutrami ${ }^{10}$. Rzeczony kościół cały w dubelt gontami ${ }^{11}$ obity i czerwono obmaliowany. Krzyżów na tym kościele nowych cztery. Okien większych w ołów oprawnych 8 , nad chórem okno 1, a drugie w szczycie mniejsze podobne pierwszemu, w zakrystyi okien dwa w ołów oprawne, z kratami żelaznemi. Drzwi, wchodząc, dębowe, podwójne ćwiekami nabite, obmaliowane czerwono na zawiasach $z$ zasuwką. Drugie drzwi dębowe do zakrystyi na zawiasach z zamkiem wnętrznym obmaliowane czerwono, z zakrystyi do kościoła drzwi podwójne na zawiasach z zamkem wnętrznym od frontu są dwa smoki z blachy dla spadu wody obmaliowane czerwono. Cały kościół wewnątrz wybieliony, a lamperyje koło okien i drzwiów popieliato, a znadworza czerwono we środku tego kościoła znajduje się część filiarów murowanych dla utrzymywania belek. Posadzka w kościele z cegieł a w prezbiterium z marmuru. Organ o ośmiu głosach obmalowany biało, a w niektórych miejscach fungultem ${ }^{12}$ ozdobiony i nowo reperowany. Ambona zieliono malowana. Krzcielnica ośmiugranna ${ }^{13}$, obmalowana popielatą. Ławek dwanaście, z tych w prezbiterium trzy malowanych czerwono. Konfesjonałów dwa, krzesło dla celebransa jedno, w zakrystii jedno.

\section{Oltarze. Pierwszy - wielki oltarz}

Biało malowany i w wielu miejscach fungultem ozdobiony $\mathrm{z}$ mensą ${ }^{14} \mathrm{o}$ trzech stopniach z umieszczonym na niej portatilem ${ }^{15}$ i cymborium ${ }^{16}$ [sic!] biało malowanym w którym się utrzymuje Sanctissimum, drzwiczki do cymborium na zawiasach z zameczkiem wnętrznym w tym ołtarzu figura Pana Jezusa u słupa uwiązanego wyżej zaś znajduje się obraz Matki Boskiej.

${ }^{5}$ Arszyn - dawna rosyjska miara długości wahająca się w granicach 71,1-81,5 cm.

${ }^{6}$ Facjata - określenie przestarzałe, oznacza środkową część ściany frontowej budynku wysuniętą ponad gzyms.

${ }^{7}$ Tarcica - deski otrzymywane z pocięcia okrągłego drzewa równolegle do ich osi podłużnych, np. ciąć drzewo na tarcice.

${ }^{8}$ Lisicami - winno być listwami.

${ }^{9}$ Sworzeń - element konstrukcyjny, zwykle w kształcie wałka lub stożka, służący do łączenia dwóch lub więcej elementów w sposób umożliwiający ich obracanie się.

${ }^{10}$ Mutra (niem.) - nakrętka.

${ }^{11}$ Gont - deszczułka klinowa używana do pokrycia dachów lub szalowania zewnętrznych ścian budynków.

${ }^{12}$ Fungult (niem. funkeln błyszczeć, lśnić; Gold złoto) tu - w znaczeniu: złotem malarskim, fałszywym złotem.

${ }^{13}$ Granna - staropolskie grań oznacza bok, krawędź, kąt, szczyt góry, granicę. Tu w znaczeniu chrzcielnica ośmiokątna.

${ }^{14}$ Mensa (łac. stół) - płyta z piaskowca lub marmuru, stanowiąca zasadniczą część ołtarza.

${ }^{15}$ Portatyl - ołtarzyk przenośny w kształcie kamiennej tablicy z relikwiami, zastępujący stały ołtarz lub kładziony na ołtarzach niepoświęconych przez biskupa.

${ }^{16}$ Cyborium (łac.) - tu: tabernakulum. 


\section{Oltarz drugi}

Świętego Antoniego, w nim obraz na płótnie malowany w ramach drewnianych, malarską pozłotą powleczonych, w górze nad tym obrazem figura maleńka Ś. Ducha, drewniana z promieniami także drewnianemi, po bokach zaś znajdują się aniołki i inne ozdoby. W tym ołtarzu gradusa ${ }^{17}$ o jednym stopniu $z$ umieszczonym na nim portatelem [sic!].

\section{Oltarz trzeci}

Świętego Franciszka, w nim obraz duży na płótnie maliowany, w ramach drewnianych, maliarską pozłotą powleczonych, gradus w jednym stopniu, naokoło tego obrazu znajdują się snycerskiej ${ }^{18}$ roboty gzymsa, trzy także maliarską pozłota powleczone i inne ozdoby, a jako do tego ołtarza nie ma portatella [sic!] z relikwijami świętymi, to i Msza święta przed nim się nie odprawia.

\section{Srebro kościelne}

Monstrancyj 2 srebrnych, w promieniach wyzłacanych.

Puszka srebrna na komunikanty, wyzłacana.

Kielichów srebrnych z patynami ${ }^{19}$ wyzłacanych cztery, $\mathrm{z}$ tych dwa potrzebują reperacji.

Puszka srebrna wyzłacana, dla chorych, jedna.

Puszka bez pozłoty, srebrna, dla chorych, jedna.

Krzyż z figurą Pana Jezusa jeden, posrebrzany.

Pacyfiga ${ }^{20}[$ sic!] z relikwiami Ś.Ś. Kazimierza i Jana, jeden.

Koronka mała na obrazie Matki Boskiej, ozdobiona 25 kamykami szklanemi, jedna.

Krzyż z figurą pana Jezusa, srebra warszawskiego, jeden.

Ampułek para jedna z tacką srebra warszawskiego.

Trybularz z łódką i łyżeczką, także srebra warszawskiego.

Lichtarzyków srebra warszawskiego, para jedna.

\section{[k. 3] Ornaty białe}

1. Ornat biały i materialny z kolumną takąż, w kwiaty różnego koloru, obwiedziony taśmą jedwabną, biało podszyty astrachanią ${ }^{21}$ czerwoną $\mathrm{z}$ manipularzem $^{22}$.

2. Ornat materialny w kwiaty, obwiedziony taśmą jedwabną białą, podszyty astrachanią karmazynową starą, z rekwizytami, stary.

\footnotetext{
${ }^{17}$ Gradus (łac.)- stopień.
}

${ }^{18}$ Snycerstwo - rzemiosło artystyczne, sztuka rzeźbiona w drewnie, dawniej także w kamieniu.

${ }^{19}$ Patena (łac. miska) - płaska, okrągła, zwykle złota lub pozłacana tacka, na której kładzie się hostię..

${ }^{20}$ Pacyfikał (łac. pacificus czyniący pokój) - rodzaj relikwiarza w kształcie krzyża lub niewielkiej monstrancji, podawany wiernym do oddania czci relikwiom, a podczas wizytacji parafialnej biskupowi do ucałowania przy wejściu do świątyni.

${ }^{21}$ Astrachania - barwna tkanina bawełniana lub półbawełniana o jedwabnej osnowie.

${ }^{22}$ Manipularz (łac. manus ręka) - pas tkaniny przypominający stułę, w kolorze dostosowanym do szat mszalnych, ozdobiony na środku krzyżykiem, używany był (do Vaticanum II) przez duchownych na lewym przedramieniu w czasie sprawowania liturgii eucharystycznej. 
3. Ornat gredyturowy $\mathrm{y}^{23} \mathrm{w}$ kwiaty różnego kolory obwiedziony galionem ${ }^{24}$ szychowym ${ }^{25}$ białym wąskim, podszyty astrachanią szafirową z rekwizytami.

4. Ornat biały gredyturowy w kwiaty srebrne z kolumną atłasową ${ }^{26}$, bladoróżową, w kwiaty srebrne i jedwabne różnego koloru, obwiedziony galonem srebrnym podszyty i kitajką ${ }^{27}$ niebieską.

5. Ornat biały adamaszkowy ${ }^{28} \mathrm{z}$ kolumną lamową ${ }^{29}$, włóczką w kwiaty ozdobiony, podszyty mamisem ${ }^{30}$ niebieskim obwiedziony galonikiem pozłacanym, cały ze swemi rekwizytami.

6. Ornat cały lamowy srebrny, podszyty muślinem ${ }^{31}$ czerwonym obwiedziony galonem złotym, cały ze swemi rekwizytami.

\section{Ornaty czerwone}

1. Ornat czerwony w krzyżyki srebrne wyszywany, obwiedziony galonikiem srebrnym, podszyty astrachanią niebieską, z rekwizytami.

2. Ornat czerwony gredyturowy w kwiaty białe z kolumną aksamitną czerwoną, obwiedziony około kolumny galonikiem żółtym szychowym, astrachanią niebieską podszyty, z rekwizytami.

3. Orant czerwony z materii tureckiej stary, z kolumną ciemnozieloną, gredyturową, w kwiaty, obwiedziony galonem białym szychowym, podszyty kitajką starą różnych kolorów, z rekwizytami.

4. Ornat czerwony kamlotowy ${ }^{32}$, z kolumną zieloną, obwiedziony taśmą białą,

${ }^{23}$ Grodetur, gradytur, gredytur, grodytur, grodetur (franc. gros de Tours) - gęsta tkanina jedwabna o splocie grodeturu, rodzaj kitajki średniej grubości, barwiona na różne kolory, czasem wzorzysta.

${ }^{24}$ Galon - wyrób pasamoniczny w formie gładkiej lub wzorzyście tkanej taśmy, wykonanej częściowo lub całkowicie z nitek metalowych, metalizowanych, jedwabnych lub bawełnianych. Galony używano do ozdabiania odzieży, szat liturgicznych a także oznaczania dystynkcji wojskowych na mundurach.

${ }^{25}$ Szych, sych, nędza - przędza lniana lub bawełniana okręcona spiralnie posrebrzanym lub pozłacanym paseczkiem miedzianym,.

${ }^{26}$ Atłas - jednostronnie błyszcząca, gładka lub wzorzysta tkanina jedwabna lub półjedwabna, z lnianym albo bawełnianym wątkiem.

${ }^{27}$ Kitajka (ros. Kitaj Chiny) - cienka, dość gęsta, gładka, lśniąca tkanina bawełniana lub jedwabna o splocie płóciennym, jednobarwna lub mieniąca się.

${ }^{28}$ Adamaszek - tkanina dwustronna, najczęściej jedwabna, zwykle jednobarwna, z błyszczącym wzorem na matowym tle lub odwrotnie.

${ }^{29}$ Lama - gładka lub wzorzysta tkanina jedwabna o tle całkowicie lub częściowo pokrytym dodatkowym wątkiem metalowym złotym albo srebrnym, wyjątkowo obydwoma, często w postaci pasków folii. Używana na bogate ubiory, na szaty liturgiczne od XVIII wieku do dziś.

${ }^{30}$ Mamis - zapewne błędnie zamiast: tamis - tkanina z długiej wełny czesankowej dobrego gatunku.

${ }^{31}$ Muślin, muszyn, muślinett - bardzo cienka, rzadka i delikatna tkanina bawełniana o splocie płóciennym, zazwyczaj gładka, rzadziej tkana w paski czy kratki lud drukowana w kwiaty i inne wzory, niekiedy haftowana.

${ }^{32}$ Kamlot, czamlet, szamlot (gr. kamelos wielbłąd) - tkana, cienka, dość rzadka tkanina z szorstkiej wełny czesankowej gorszego gatunku. Wyrabiana z wełny koziej lub wielbłądziej, lub gorszej wełny owczej na osnowie jedwabnej, lnianej lub półjedwabnej, a nawet czasami konopnej. 
podszyty astrachanią bladoróżową, z rekwizytami.

\section{Ornaty zielone}

1. Ornat zielony adamaszkowy, obwiedziony galonem szychowym, białym, podszyty astrachanią bladą różową, z rekwizytami.

2. Ornat zielony gredyturowy stary, podszyty szychem białym, obwiedziony starą białą korunką, podszyty kitajką orzechową starą.

\section{Ornaty żólte}

1. Ornat z materyi żółtej, z kolumną popielatą morową, podszyty kartunem ${ }^{33}$ niebieskim, obwiedziony galonikiem srebrnym, pełny, ze swemi rekwizytami.

\section{Ornaty szafirowe}

1. Ornat szafirowy materialny, podszyty kartunem czerwonym, obwiedziony galonikiem, cały ze swemi rekwizytami.

\section{Ornaty fioletowe}

1. Ornat fioletowy adamaszkowy, z kolumną adamaszkową bladoróżową, obwiedziony galinem szychowym białym, podszyty astrachanią różową, z rekwizytami.

2. Ornat fioletowy grodyturowy, z kolumną wyszywaną różnych kolorów kwiaty, obwiedziony galonem srebrnym starym, podszyty astrachanią niebieską, z rekwizytami.

\section{Ornaty czarne}

1. Ornat czarny gredyturowy, obwiedziony galonem szychowym żółtym, podszyty astrachanią czerwoną, z rekwizytami.

2. Ornat czarny gredyturowy, obwiedziony galonem szychowym białym, astrachanią podszyty czarną, z rekwizytami.

3. Ornat czarny atłasowy z kolumną gredyturową, galonikem szychowym obwiedziony, bez rekwizytów, popruty. Stary.

\section{Dalmatyki}

Dalmatyk ${ }^{34}$ czarnych atłasowych dwie, w krzyżyki srebrne, obwiedzione galonem srebrnym, podszyte astrachanią koloru niebieskiego.

\section{Kapy}

1. Czerwona, atłasowa w krzyżyki srebrne, obwiedziona galonikiem srebrnym z jedwabiem przetykanym, podszyta astrachanią niebieską.

2. Zielona, adamaszkowa, mająca kwiaty złote przeszywane srebrem i jedwabiem; kaptur ma blado różowy w kwiaty złote i srebrne szlakiem żółtym, przerabiana około kaptura, obwiedziona fręzlą złotą i z kutasem takimże, astrachanią ciemną zieloną podszyta.

3. Czarna, adamaszkowa, obwiedziona galonem szychowym białym, podszy-

${ }^{33}$ Kartun, karton, kartonada (fr. carton, wł cartone) - barwnie drukowana tkanina bawełniana lub o osnowie lnianej i wątku bawełnianym, zwykle o splocie płóciennym, maglowana, lżejsza i tańsza od cycu. Wyrabiany w Europie Zachodniej od XVII wieku, w manufakturach polskich od 2. połowy XVIII wieku. Używany jako lekka tkanina odzieżowa, a także obiciowa.

${ }^{34}$ Dalmatyka - szata liturgiczna diakona w formie krótkiej, luźnej tuniki, z szerokimi i krótkimi rękawami. Diakon nakłada dalmatykę na albę i stułę. Jest ona zawsze w kolorze ornatu celebransa. 
ta astrachanią czarną.

\section{Bursy}

Czerwone, aksamitne, podszyte kitajką zieloną w kwiaty, dwie.

\section{Firanki}

1. Koloru saladynowego, gazowe, z koronką szychową białą jedna.

[k. 4] 2. Piusowe, gazowe, obwiedzione szychem dokoła, jedne.

3. Białe, gazowe, jedne.

4. Karmazynowe, kitajkowe, jedne.

5. Muślinem w kwiaty wyszywane, jedne.

6. Gazowe, jedne.

\section{Bielizna kościelna}

1. Alba ${ }^{35}$ płótna holenderskiego $\mathrm{z}$ koronką u dołu podszyta kolorem różowym.

2. Alba z płótna holenderskiego z falbaną u dołu, podszyta płótnem ordynarejnym [sic!].

3. Alba płótna pruskiego, stara, z korunką starą, astrachaniem niebieskim podszyta.

4. Alb płótna pruskiego, starych, z koronkami wąskiemi, dwie.

5. Alba płótna holenderskiego, z korunką starą, jedna.

6. Alba kartunowa, z korunką wyszywaną u dołu, podszyta kartunem czerwonem.

7. Alba kartunowa, z koronką u dołu szeroką, w kwiaty, podszyta kartunem czerwonym.

8. Komża nowa płótna szwabskiego, z koronką, wyszywana jedna.

9. Komża z koronkami staremi, jedna.

10. Komż starych dla lekwitorów ${ }^{36}$ [sic!] cztery.

11. Komeszek kartunowych w kwiaty, dwie.

12. Komeszek kartunowych codziennych, dwie.

13. Obrusów z koronkami, adamaszkiem karmazynowym podszytych, dwie.

14. Ordynaryjnych, nowych, cztery.

15. Obrusów muślinowych, wyszywanych w kwiaty, dwa.

16. Humerałów ${ }^{37}$ cieńszych cztery.

17. Humerałów grubszych cztery.

18. Humerałow holenderskiego płótna sześć.

19. Korporałów ${ }^{38}$ holenderskiego płótna sześć.

${ }^{35}$ Alba (łac. albus biały) - długa do kostek szata liturgiczna z szerokimi rękawami, wykonana z białego płótna, tradycyjnie sporządzona z lnu. Jest symbolem czystości duszy, zdobytej przez krew Baranka.

${ }^{36}$ Lekwitorów - winno być: lektorów.

${ }^{37}$ Humerał (łac. humerale od humerus bark) - część stroju liturgicznego w postaci białej chusty nakładanej na ramiona pod albę aby przykryć zwykły ubiór koło szyi.

${ }^{38}$ Korporał (łac. corporale od corpus ciało) - lniany, kwadratowy obrus, który podkłada się pod kielich i patenę w czasie celebrowania Mszy Świętej. Jest umieszczany także w tabernakulum, w bursie, na stole ołtarzowym pod monstrancją, pod puszkami z Najświętszym Sakramentem, na ołta- 
20. Korporałów innego gatunku płótna dziesięci.

21. Puryfikaterzów ${ }^{39}$ osiemnaście.

22. Ręczników zakrystyjnych dziesięć.

23. Ręczników do ołtarzów sześć, starych, a trochu lepszych sześć, w ogóle dwanaście.

24. Pasków nieciasnych trzynaście.

\section{Obrazy ścienne}

Ukrzyżowanie Pana Jezusa jedne na papierze, a drugą [sic!] na płótnie maliwane, [sic!] stare. Niepokalianego [sic!] poczęcia Matki Boskiej na papierze 2. Bolesnej Najświętszej Panny na płótnie 1. Ś. Jana Ewangelisty na papierze 1. ŚŚ. Trójcy na płótnie, stary 1. Świętego Jana Chrzciciela na płótnie 1. Świętego Brunona, drugi Świętego Benedykta 1. Pana Jezusa ukrzyżowanego na płótnie 1. Matki Boskiej także na płótnie 1. Poduszek pod mszały na ołtarzy trzy, pokryciów na ołtarzy cyratowych 2 . Rezurekcyjna 1 . Krzyżyków z pasyjkami małych dwa. Luster dwa, jedno stare, drugie nowe. Umbraculum ${ }^{40}$ trzy, jedna z nich do puszki z paciurek gustownie zrobione. Lichtarzy drewnianych malowanych sześć. Wazonów z kwiatami dwa. Katafalów ${ }^{41}$ dwa, jeden o dwóch, a drugi o trzech stopniach z czterema trójkątami na osadzenie lamp. Tablica marmurowa 1.

Przy kościele znajduje się drewniana dzwonnica o dwóch piętrach, na drugim zawieszone trzy dzwony, pokryta gontami, do której drzwi drewniane, stolarskiej roboty, na dwóch krukach ${ }^{42}$ żelaznych z klamką i zaszczepką także żelazną. Dzwony jeden duży, drugi średni, trzeci najmniejszy. Sygnaturka, dzwonków małych przy ołtarzach trzy, do bursy ${ }^{43}$ dwa. Dzwonek przy zakrystyi jeden, przy którym pasek włóczkowy, gustownie zrobiony.

\section{Chorągwie}

Chorągwi karmazynowych 2. Czarna 1. Sztandar blidoróżowy [sic!] jeden, a nowo przybyłych chorągwi czarnych adamaszkowych 2 i sztandarów 2 . Baldachim adamaszkowy, zielony, stary 1, a drugi o dwóch liaskach [sic!], adamaszkowy, karmazynowy, podszyty, dokoła obwiedziony maszestrem ${ }^{44}$ i galionikiem.

rzach procesji Bożego Ciała, w grobie Pańskim, na kredencji w czasie puryfikacji. Korporał krochmali się i składa do środka na dziewięć części.

${ }^{39}$ Puryfikaterz (łac. purificare oczyszczać) - niewielkich rozmiarów podłużny płócienny ręczniczek, złożony na trzy części, służący do wycierania i osuszania naczyń liturgicznych, obmytych uprzednio wodą (czynność tę nazywa się puryfikacją).

${ }^{40}$ Umbraculum (łac. miejsce ocienione) - parawan na stojaku z emblematem JHS, służący do zasłaniania monstrancji z Najświętszym Sakramentem podczas nabożeństw liturgicznych, np. w czasie głoszenia kazania.

${ }^{41}$ Katafalk - podwyższenie, na którym w kościele lub kaplicy pogrzebowej stawia się trumnę w czasie mszy pogrzebowej i obrzędu ostatniego pożegnania.

${ }^{42}$ Kruk (z ros. крюк) - hak.

${ }^{43}$ Bursa (łac. mieszek) - usztywniona, najczęściej kwadratowa torebka z tkaniny, służąca do przenoszenia Komunii Świętej do chorych.

${ }^{44}$ Manszester, menczester, manszestr (od ang. Manchester) - runowa tkanina bawełniana o podłużnych, bardzo szerokich prążkach z okrywy włókiennej, tkanina splotem okrywowym wątkowym, jednobarwna. Zastępowała niegdyś droższe aksamity jedwabne. 
W zakrystyi mensa do ubierania się na Mszą o trzech szufladach większych i trzech mniejszych $z$ antabami ${ }^{45}$ żelaznymi jedna. Antepedium ${ }^{46}$ do wielkiego ołtarza $\mathrm{z}$ włóczki w kolorach różnych w ramy wyzłacane oprawne. Dywan nowy o 4-ch brytach ${ }^{47} \mathrm{z}$ włóczki różnych kolorów gustownie zrobiony cały podszyty płótnem prostym grubym paczesnym ${ }^{48}$.

\section{Miedz, mosiądz, cyna i żelazo}

Kociołek do wody chrzestnej stary, jeden.

Miednica, w której stawi się liampa [sic!] jedna.

Kociołek do wody święconej na aspersyją ${ }^{49}$ jeden.

Kubek do wody jeden.

Lichtarzy większych, cynowych, cztery.

Lichtarzy małych, cynowych, dwa.

Ampułek dwie.

Puszek na oleja ŚŚ., trzy.

Lichtarzów mąsiężnych [sic!] małych pobielanych dwa.

Tyrbulum [sic!] z łańcuszkiem, mosiężne, jeden.

Lichtarz mosiężny, nowy, jeden.

Forma do pieczenia opłatków, jedna.

Forma do robienia komunikantów, jedna.

Szczypce żelazne, m[os]iężne, jedne.

Krzyżyków czuhunnych ${ }^{50} \mathrm{z}$ figurami Pana Jezusa, dwa.

\section{[k. 5] Księgi kościelne}

Mszałów łacińskich dwa. Ajentka [sic!] jedna. Ajentka mała jedna. Brewiarz jeden. Ewangeliczka jedna.

\section{Akta kościelne}

Książka ślubna metryczna od roku 1748. Książka metryk ślubnych nowej formy od No 27. Książka metryk chrzestnych od roku 1745. Książka metryk nowo narodzonych od roku 1790 . Książka metryk chrzestnych nowej formy od roku 1827. Książka metryk chrzestnych nowej formy od roku 1843. Książka egzaminów przedślubnych od roku 1827 . Książka egzaminów przedślubnych od roku

${ }^{45}$ Antaba (niem. Handhabe) - uchwyt, rękojeść, rączka.

${ }^{46}$ Antependium (łac. antependere wisieć przed) - ozdobna zasłona podstawy ołtarza od mensy do suppedaneum, spełniająca w liturgii rzymskiej rolę frontu ołtarza. Od XIII wieku stanowiła je rozpięta na drewnianej ramie (telaria) tkanina z jedwabiu i innych tkanin, przyozdabianych szlachetnymi kamieniami, haftami, malowidłami, złotem. Zalecano dostosowanie koloru antepedium do okresu liturgicznego. Po odnowie liturgicznej Vaticanum II usunięte z ołtarza.

${ }^{47}$ Bryt, bret (niem. Breite szerokość) - szerokość tkaniny od krajki do krajki. W krawiectwie także określenie klina lub pasa tkaniny, np. płaszcz z brytem.

${ }^{48}$ Pacześne płótno, paczesne płótno - cienkie, średniej jakości płótno lniane z lepszych odpadków z czesania włókna na drugiej szczotce.

${ }^{49}$ Aspersja (z łac. aspergere - pokropić) - obrzęd pokropienia wiernych pobłogosławioną wodą podczas Mszy Świętej. Jest to jedna z form aktu pokuty na początku liturgii. Przypomina uczestnikom sakrament chrztu św., który oczyszcza z grzechów i włącza do wspólnoty Kościoła. Ta forma aktu pokuty jest zalecana w każdą niedzielę, szczególnie jednak w okresie wielkanocnym.

${ }^{50}$ Czuhunny - żelazny, żeliwny. 
1835. Książka egzaminów przedślubnych od roku 1843. Książka metryk pogrzebowych od roku 1746. Książka metryk pogrzebowych od roku 1827. Książka pod tytułem Status animarum od roku 1827. Książka ukazów rządowych od roku 1804. Książka zaleceń pasterskich od roku 1802. Książka wizytna inwentarzowa od roku 1804.

\section{Biblioteka kościelna}

Kazania w gotyckim druku ks. Skargi ${ }^{51}$ bez początku 1. Księga pierwsza obrawienie [?] niebieską 1. Kazania na niedziele doroczne przez ks. Binedykta [sic!] od Ś. Pana 1. Kazania dwojakie na niedzieli całego roku przez ks. Franciszka Rychławszego ${ }^{52} 1$. Kazania całego roku i święta Chrystusowe od ks. Bonawentury Guliurowskiego $^{53}$ 1. Dzieło zbawienia ludzkiego 1. Kwadragizyma $[\mathrm{sic!}]^{54} 1$. Elementarzyk ćwiczenia duchownego ${ }^{55} 1$. Regest ŚŚ. Ewangelij do kazań 1 . Adama Ignacego Komorowskiego ${ }^{56}$ 1. - Sacrum pancarpium Dominicale ${ }^{57}$ 1. Andreae Załuski $^{58}$ 1. Dicenda concionatorum [?] 1. Notitia Commitiorum 1. Conpendium

${ }^{51}$ Ks. Piotr Skarga, właściwie Piotr Powęski (1536-1612), jezuita, teolog i pisarz. Nadworny kaznodzieja Zygmunta III Wazy. Oskarżał szlachtę o egoizm stanowy i warcholstwo. Swoje poglądy na zagadnienie państwa i sprawowania władzy przedstawił w Kazaniach sejmowych (wydane w r. 1597) w zbiorze: Kazania na niedziele i święta całego roku. Zawierają 8 kazań, które nigdy nie zostały wygłoszone. Omawiają najważniejsze postulaty dotyczące reformy państwa, skierowane są przeciw ideom reformacyjnym.

${ }^{52}$ Ks. Rychłowski Franciszek (1611-1673), polski franciszkanin, kaznodzieja, prowincjał. Wydał m.in.: Kazania na niedziele całego roku (Kraków 1660), Kazania na święta całego roku (Kraków 1667), Kazania na święta Panny Przenajświętszej (1657). Por. M. Nowodworski, Encyklopedia kościelna, t. 23, Warszawa 1899, s. 608-609.

${ }^{53}$ Ks. Gelarowski (Gielarowski) Bonawentura (1657-1711), jezuita, autor wznawianych dwukrotnie kazań: Kazania na niedziele całego roku i Święta Chrystusowe od X. Bonawentury Gelarowskiego Soc. Jesu miane, Toruń 1727, Sandomierz 1738.

${ }^{54}$ Stanisław Bzowski, Bzovius (1567-1637), dominikanin, imię zakonne Abraham. Kaznodzieja, mariolog, hagiograf, historyk Kościoła. Ogłosił 33 dzieła, zwłaszcza z kaznodziejstwa, mariologii, hagiografii i historii Kościoła. Spuścizna kaznodziejska Bzowskiego dzieli się na trzy grupy: kazania niedzielne, na cześć NMP i ku czci świętych. Tu chodzi o kazania wielkopostne Conciones quadragesimales, ex floribus S. Scripturae et SS. patrum, super Evang. quae in Dominicis et pro festis diebus totius quadragaesimae leguntur, desumptae, wydane w Kolonii 1613, 1717. Por. J. Duchniewski, Bzowski, Bzovius Stanisław, EK t. 2, Lublin 1995, k. 1261-1262.

${ }^{55}$ Mikołaj z Mościsk, Mikołaj Mościcki (1559-1632), dominikanin, moralista, teolog duchowości. Napisał Elementarzyk ćwiczenia duchownego, drukowane w Krakowie 1626. Por. J. Popławski, Mikołaj z Mościsk, Mikołaj Mościcki, EK, t. 12, Lublin 2008, k. 1010-1011.

${ }^{56}$ Komorowski Adam Ignacy (1699-1759), arcybiskup gnieźnieński, prymas Polski, doktor obojga praw, wybitny homiletyk, otrzymał Order Orła Białego, stronnik familii Czartoryskich. Dbał o rozwój kaznodziejstwa i katechizacji wydając pod swoim nazwiskiem, m.in. Regestr S.S. Ewangelii na niedziele i święta doroczne do kazań (Warszawa 1758). J. Warmiński, Komorowski Adam Ignacy abp, EK, t. 9, Lublin 2002, k. 473-474.

${ }^{57}$ Chodzi o kazania niedzielne Abrahama Bzowskiego (1567-1637) Sacrum pancarpium Dominicale totius anni ex floribus Sacrae Scripturae, wydane w 1611.

${ }^{58}$ Załuski Andrzej Chryzostom, herbu Junosza (1650-1711), kaznodzieja, thumacz, kanclerz wielki koronny od 1703, biskup kijowski od 1683, płocki od 1692, warmiński od 1699. Był angażo- 
privilegatorum $^{59}$ 1. Theologia Dogmatico spe[culativa ?] 1. Conpendium Theologiae 1. Gramatica alias Literatura 1. Theologia Moralis universa ${ }^{60} 1$. Medulla Theologiae Moralis ${ }^{61} 1$. Nova omnia 1 . Vita et doctrina Iesu Christe ${ }^{62} 1$. De vanitate consiliorum ${ }^{63}$ 1. Fortuna Domestica 1. Manuale parochi ${ }^{64}$ 1. Rituale Sacramentorum $^{65}$ 1. Magistris scholarum inferiorum ${ }^{66} 1$. Uwagi chrześciańskie ${ }^{67} 1$. Człowiek chrześcijański ${ }^{68}$ bez początku 1.

wany do poselstw dyplomatycznych. Kanonik pułtuski i łęczycki, opat komendatoryjny wąchocki oraz prepozyt jarosławski. Autor kazań, mów i tłumacz dzieł ascetycznych.

${ }^{59}$ Rękopis: Series archivorum regni seu compendium pactorum, foederum, tractatuum [...] nec non privilegiorum [...] insuper inscriptionum variarum et transactionum in archiwo regni [Poloniae] reperibilium summarie [...] conscriptum anno salutis 1730 Cracoviae. Ukazały się także opracowania przywilejów papieskich poszczególnych zakonów, m.in. Compendium Privilegiorum et Gratiarum Societatis Jesu, z 1635 oraz Alonsa de Cesarubios Compendium Privilegiorum Fratrum Minorum Et aliorum Mendicantium, \& non Mendicantium, wydane 1619.

${ }^{60}$ Pauli Gabrielis Antoine (1678-1743), jezuita francuski. Napisał dzieło: Theologia moralis universa, wydana w Nancy 1731, następnie w Paryżu 1736. Przez długi czas było ono głównym podręcznikiem używanym w seminariach francuskich i włoskich, a także w niektórych seminariach w Niemczech i w Polsce. Por. M. Nowodworski, Encyklopedia kościelna, t. 1, Warszawa 1873, s. 267.

${ }^{61}$ Chodzi o podręcznik teologii moralnej H. Busenbauma (1600-1668), wydany po raz pierwszy w Kolonii w r. 1645.

${ }^{62}$ Dzieło Nicola Avanciniego (1611-1686), jezuity, poety i pisarza włoskiego: Vita Et Doctrina Jesu Christi, ex Quatuor Evangelistis collecta, et in meditationum materiam ad singulos totius anni dies distributa, wydane w Wiedniu w r. 1674. Książka ta miała przeszło 50 wydań i przekładów, m.in. na język polski autorstwa A. Jełowickiego (Rok Chrystusowy, Poznań 1850 i 7 następnych wydań w Berlinie, Paryżu, Krakowie i Warszawie. Por. T. Obłąk, Avancini Nicolaus, EK, t. 1, Lublin 1985, k. 1171.

${ }^{63}$ Prawdopodobnie chodzi o dzieło Stanisława Herakliusza Lubomirskiego, wydane w r. 1699, a następnie wielokrotnie wznawiane (przekład polski O próżności rady 1705 i in.) .

${ }^{64}$ Franciscus Herzig, Manuale parochi: seu methodus compendiosa munus parochi apostolicum rite obeundi, wydał Veith 1757.

${ }^{65}$ Rituale sacramentorum ac aliarum Ecclesiae caeremoniarum ex decreto synodi privinc[ialis] Petricovien[sis] ad uniformem ecclesiarium Regni Polon[iae] et M. Ducatus Lith[uaniae] usum recens et in breve opusculum editum, cum scitu et promissu Officii, wydane 1647.

${ }^{66}$ Joseph de Jouvancy, Jouvency (1643-1719), jezuita francuski, filolog klasyczny. Jest autorem słownika mało znanych wyrażeń i zdań wybranych autorów greckich i łacińskich $\mathrm{z}$ ich idiomami francuskimi: Christianis litterarum magistris de ratione discendi et docendi, Paris 1692. Wydanie oficjalnie zatwierdzone do użytku w zakonie przez nauczycieli pt. Magistris scholarum inferiorum Societatis Jesu de ratione discendi et docendi; ex decreto congregationis generalis XIV, wydane we Florencji 1703 jako przewodnik metodyczny dla nauczycieli języków klasycznych. Przygotował także do użytku szkół wybór łacińskich tekstów starożytnych pisarzy i poetów. Por. M. Daniluk, Jouvancy, Jouvency Joseph de SJ, EK t. 8, Lublin 2000, k. 99.

${ }^{67}$ Chodzi o dzieło Dominique'a Bouhourusa (1628-1702), francuskiego jezuity, pisarza religijnego i krytyka literackiego: Uwagi Chrzescianskie na Kazdy dzien (Uwagi chrześcijańskie na każdy dzień), wydane w Sandomierzu 1748. Por. K. Leń, Bouhourus Dominique, EK, t. 2, Lublin 1995, k. 849.

${ }^{68}$ Piętanaście stopni, Po których człowiek, zwłaszcza krześciański, upatrując Pana Boga w stworzeniu rozmaitym, przychodzi do wielkiej znajomości jego. Opisane przez Roberta Kardinała 


\section{Zabudowanie plebanialne}

Dom mieszkalny, wchodząc na dziedziniec, brama z tarcic podwójna stolarskiej roboty na czterech krukach żelaznych, w której są drzwi z zaszczypką żelazną, wprost od tej bramy plebania, czyli budynek mieszkalny w roku $1815 \mathrm{z}$ drzewa wystawiony z gankiem o dwóch słupach okrągłych, cały takowy budynek na podmurowaniu gontami pokryty, z [sz]czytami dwuma z tarcic robionemi, w których są dwa okna, małych, o jednym kominie murowanym, stajni w tym budynku cztery, równej odległości, sionki o chudobu ${ }^{69}$ jedne, podłoga i sufit z tarcic, w tym budynku znajduje się drzwiów sześcioro, z tych jedne podwójne, stolarskiej roboty, z okuciem przyzwoitym, z zamkami wnętrznemi okien w tymże domu osim, każde okno ma po osim szyb, z okuciem wszelkim, przy każdym oknie okiennica na krukach żelaznych z zaszczepką i probojami żelaznemi, pieców ceglanych fizycznych dwa, z drzwiczkami żelaznemi i juszkami ${ }^{70}$ czuhunnemi, szafa w murze z czterema półeczkami, drzwi do niej olchowe, malowane, na zawiaskach i zaszczepką wnętrzną. Dom czeladny, w roku 1816 z drzewa postawiony, słomą pokryty, o jednym kominie murowanym z cegły i kuchenką. Cały na podmurowaniu, w którym jest stanij cztery i dwie spiżarenki dla składu warzywa, piec chlebowy z cegły jeden, drugi piec fizyczny z drzwiczkami żelaznymi i juszką, sufit z tarcic, podłoga z gliny. Spichlerz w roku 1817 z drzewa postawiony, drewniany, dranica$\mathrm{mi}^{71}$ pokryty, drzwi do niego na zawiasach i krukach żelaznych z zaszczepką i zamkiem wiszącym, podłoga i sufit z tarcic, na dziedzińcu studnia z kluczką ${ }^{72}$ i wiadrem, przy której koryto dla napojenia żywota. Chlew drewniany, w roku 1819 z drzewa postawiony, pokryty słomą, w nim przegród cztery, drzwi troje, każde na zawiasach i krukach żelaznych, z zaszczepką takąż.

Browarek w roku $1820 \mathrm{z}$ drzewa postawiony, pokryty słomą, i drzwi na zawiasach i krukach żelaznych, z zaszczepką takąż.

Chlewek w roku 1820 z drzewa postawiony i słomą pokryty. Drzwi na zawiasach krukach z zaszczepką żelazną.

Szopa dranicami pokryta na skład drzewa.

Przy gumnie spichlerz w roku $1830 \mathrm{z}$ drzewa postawiony, słomą pokryty. Drzwi na zawiasach, krukach żelaznych, z zaszczepką i zamkiem wewnętrznym, podłoga i sufit $z$ tarcic sosnowych na podmurowaniu.

Stodoła w roku 1803 z drzewa stawiona na dwunastu słupach, o sześciu ścianach podłużnych, a dwóch poprzecznych, słomą pokryta, drzwiów podwójnych na biegunach $^{73}$ drewnianych troje, do pierwszych drzwiów jest zaszczepka żelazna

Bellarmina [...]; Przełożył z łacińskiego na polskie przez ks. Kaspra Sawickiego, wydane w 1616.

${ }^{69}$ Chudoba - przestarzałe: skromny dobytek, ubogie mienie, gospodarstwo.

${ }^{70}$ Juszka - regionalne: wywietrznik piecowy.

${ }^{71}$ Dranica - cienka, wąska deska łupana z pnia drzewa iglastego, używana w budownictwie drewnianym zwykle do krycia dachów.

${ }^{72}$ Kluczka - rodzaj węzła, pętla ze sznura lub rzemienia zaciskająca się, służąca do przywiązywania, wiązania czegoś.

${ }^{73}$ Biegun - rodzaj drewnianych zawiasów u drzwi, pionowe czopy wystające z obrysu drzwi. Czopy obracały się w otworach, zwanych stępkami. Dawniej wszystkie drzwi mocowane były na biegunach drewnianych, następnie zastąpiły je bieguny stalowe, dziś zawiasy. 
z dwoma probojami dla zamykania na zamek wiszący, torpów dwanaście tak z gliny ubity.

Szopa pod jednym dachem ze stajnią i oborą, w roku $1835 \mathrm{z}$ drzewa stawione, słomą pokryte, w szopie dla składu siana drzwi podwójne na biegunach drewnianych z zaszczepką i zamkiem wiszącym, do stajni drzwi podwójne na biegunach drewnianych z zaszczepką i zamkiem wiszącym przegród cztery, podłoga z dylów ${ }^{74}$, a sufit żerdziami ułożony, żłób jeden, drabina jedna, takoż komórka dla składu rzeczy stajennych, drzwi do niej pojedyncze na zawiasach, krukach z zaszczepką i zamkiem wiszącym. Dalej obora do której drzwi podwójne na biegunach drewnianych z zaszczepką i zamkiem wiszącym. Dziedziniec od wschodu słońca, odgrodzony kamiennym murem i cmentarza połowa około kościoła, w jednym kawaliu, [sic!], a co zaś ogrody i zabudowania plebalne w tyli [sic!] ogrodzone kołami i płotem starym, osadzone drzewem wierzbą i część olszyny [k. 6], za domem plebalnym ogród fruktowy ${ }^{75} \mathrm{z}$ starych drzew. W ogrodzie fruktowym spichlerzyk mały, z drzewa postawiony, z gankiem o dwóch słupach sosnowych, słomą pokryty, podłoga i sufit z tracic, [sic!] drzwi jedne na krukach z zaszczepką żelazną. W rogu tego ogrodu w roku 1850 zbudowany dom dla organisty drewniany, słomą pokryty, o jednym kominie, stajnij w tym budynku dwie, jedna większa, druga mniejsza, podłoga i sufit z tarcic. Drzwiów troje z okuciem żelaznym, krukami, zawiasami i z zaszczepkami. Okien trzy w każdym oknie po 6. szyb z okuciem, piec chlebowy jeden, fizyczny jeden z drzwiczkami żelaznymi i juszkami. NB. Dom mieszkalny w 1849 roku cały gontami dubelt ubity.

\section{Inwentarz}

W roku naznaczona kommisja przez rząd dla Zabrania Majątków Duchownych na rzecz Skarbu, gdzie zabrano sześć krów funduszowych, z jakowych mają zwrócić krów trzy, a teraz nie pozostanie na Fundusz żadnej.

Naczynia gospodarskie

\begin{tabular}{|l|c|c|}
\hline & \multicolumn{2}{|c|}{ Naczynia } \\
\hline & Miedziane & Drewniane \\
\hline Łyżek warszawskiego srebra & 2. &, \\
\hline Nożów żelaznych i widelców & 2. &, \\
\hline Lichtarzy mosiężnych & 2. &, \\
\hline Moździerza z tłuczkiem & 1. &, \\
\hline Krzeseł olchowych, malowanych na czerwono &, & 6. \\
\hline Stół czworogranny, olchowy &, & 1. \\
\hline Stół okrągły o dwóch klapach, olchowy &, & 1. \\
\hline Szafa kątkowa z drzwiczkami na zawiasach i zameczkiem &, & 1. \\
\hline Dzieżab do pieczenia chleba duża & & \\
\hline
\end{tabular}

${ }^{74}$ Dyl - gruba deska używana w drewnianych budowlach, konstrukcjach stropowych, ściennych, mostowych. Tu w znaczeniu: podłoga $\mathrm{z}$ grubych desek.

${ }^{75}$ Fruktowy (od łac. fructus) - owocowy.

a Moździerz - naczynie kuchenne z tłuczkiem, najczęściej mosiężne, do ucierania na miałki proszek cukru, wanilii, pieprzu itp.

${ }^{\mathrm{b}}$ Dzieża - duże, drewniane naczynie do rozczyniania ciasta na chleb, donica. 


\begin{tabular}{|c|c|c|}
\hline Dzieża do pieczenia chleba mniejsza & 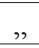 & 1. \\
\hline$\dot{Z}_{\text {Zarna }}^{\mathrm{c}}$ żelazno $[\mathrm{z}]$ porprycą $^{\mathrm{d}} \mathrm{i}$ wrzecionem ${ }^{\mathrm{e}}$ & , & 1. \\
\hline Stępa ${ }^{\mathrm{f}}$ ze stukaczem [?] & & 1. \\
\hline Kadzi $^{g}$ dla zsypania zboża & & \\
\hline
\end{tabular}

W roku 1843 naznaczona przez rząd Kommisja dla zabrania Majątków Duchownych na rzecz Skarbu zostawiła kościołowi następną ${ }^{76}$ ilość ziemi: pod zabudowaniem morgów ${ }^{77}$ sześć i 113 prętów ${ }^{78}$, oranej w uroczyskach: Nawóz - 10 morgów, Koczkowszczyźnie 17 morgów i 11 prętów, Zakłumi - 7 morgów i 114 prętów. Łąk w uroczyskach: Nawóz - 135 sążni ${ }^{79}$, Koczkowszczyźnie - 5 morgów i 280 prętów, wszystkiego włóka 1, morgów 17, prętów 53, czyli 31 dziesięcina i 512 sążni.

\section{Oznaczenie granic parafii tego kościoła}

Kościół parafialny graniczy z parafiami szereszewską, kobryńską, próżańską i zbirochowską, odległy od miasta guberńskiego Grodna o wiorst 154, od powiatowego Prużany o wiorst 35.

\section{Ludność parafii tego kościoła}

Parafian oboje płci 1173 dusz, na co utrzymuje się osobny regestr ludności. Akta zaś metryczne, zaprowadzone w roku 1745, pilnie są strzeżone przez miejscowego plebana w porządku i bezpiecznym miejscu złożone, także znajduje się Księga rozporzadzeń rzadowych i duchownych od roku 1804.

\section{Przychód}

\begin{tabular}{|l|c|c|}
\hline & \multicolumn{2}{|c|}{ Srebrem } \\
\hline A: Pensyi położono sztatem & Rubli & Kopiejek \\
\hline $\begin{array}{l}\text { B: Jako kościół kiwaczycki nie ma żadnych zaścianków, placów i domów, } \\
\text { i w roku } 1842 \text { w ruchomości nie pokazano, tak i na dochodach nic się nie } \\
\text { kładzie }\end{array}$ & 230 &, \\
\hline
\end{tabular}

c Żarna - dawne urządzenie do mielenia ziarna, składające się z dwóch płaskich, kolistych kamieni, dolnego, nieruchomego, i górnego, obracanego ręcznie.

${ }^{\mathrm{d}}$ Winno być: paprzycą. Typowe żarna rotacyjne składały się z: kamieni żarnowych, osi, paprzycy, rączki, kadłuba i mechanizmu regulującego rozstaw kamieni.

${ }^{\mathrm{e}}$ Wrzeciono - zgrubienie wiosła przy rękojeści. Tu w znaczeniu: zgrubienie na drążku (żerdki, kierownicy, żarnówki) do poruszania (mielenia) żaren przy rękojeści.

${ }^{\mathrm{f}}$ Stępa - moździerz kaszarski, prymitywne urządzenie służące dawniej do obłuskiwania i kruszenia ziarna na kaszę, składające się z drewnianej lub kamiennej misy oraz drewnianego ubijaka. Utłuc ziarno w stępie.

${ }^{g}$ Kadź - duże naczynie w kształcie stożka ściętego, mające zastosowanie w gospodarstwie domowym.

${ }^{76}$ Następną - tu: następującą.

${ }^{77}$ Morga - dawna miara powierzchni gruntu, w Polsce około $5600 \mathrm{~m}^{2}$

${ }^{78}$ Pręt - równowartość 15 stóp. Stopa - dawna jednostka miary nawiązująca do przeciętnej długości stopy ludzkiej. Różniła się wielkością w zależności od czasu i miejsca.

${ }^{79}$ Sążeń - dawna jednostka długości, używana do początku XX wieku, równa mniej więcej rozpiętości rozstawionych ramion; odpowiadał ok. 1,7 m. 


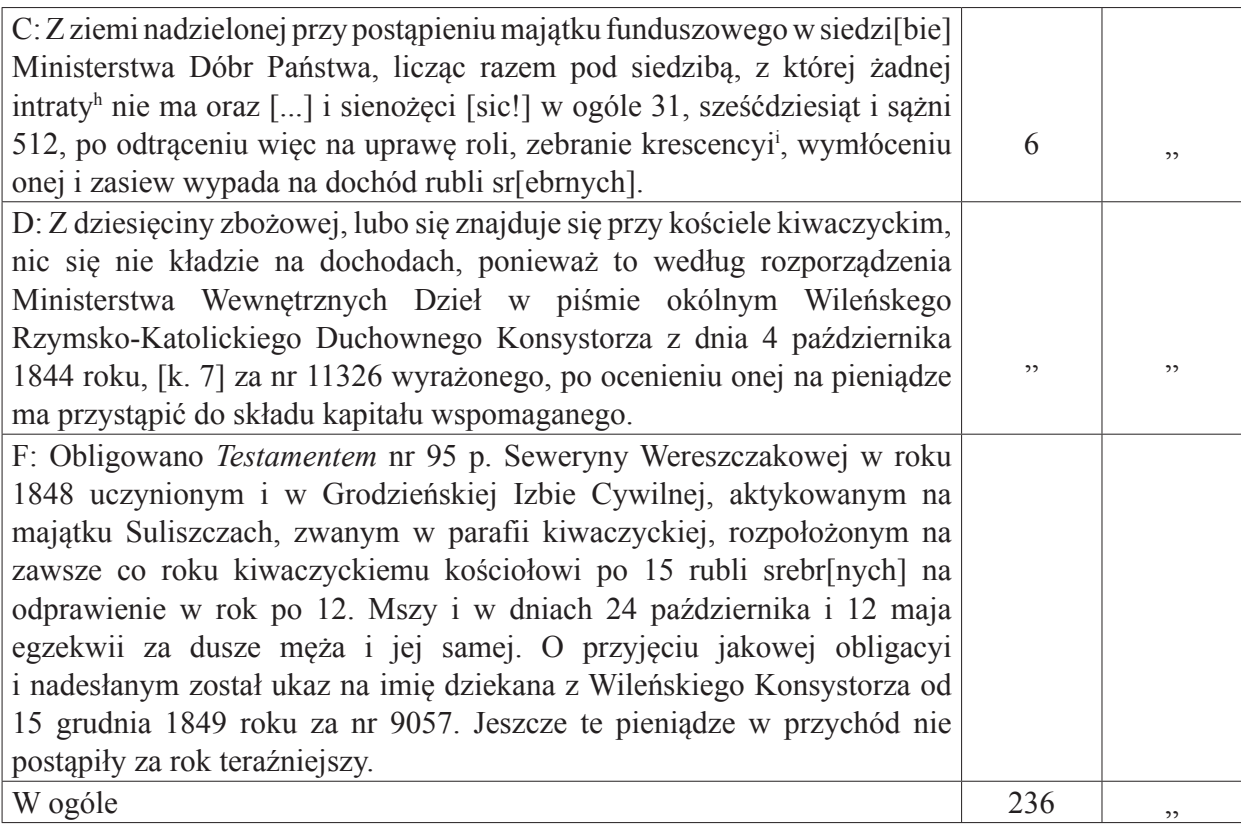

Mszy w tydzień funduszowych pięć, a w rok 260.

Aniwersarzów ${ }^{80}$ za dusze zmarłych cztery.

Szpitalów przy tem kościele żadnego nie ma.

Bractwa nigdy nie było i nie ma.

Oficjum defunctorum cztery.

Takowy Inwentarz podawczy po zgonie śp. ks. Mikołaja Bogdanowicza, następcy jego na probostwo kiwaczyckie W.J. ks. Tomaszowi Lenczewskiemu wskutek ukazu konsystorskiego z dnia 5 septembra za Nr 7933. Sporządzony przy wyciśnięciu pieczęci podpisuję. 1853 roku decembra, 18 dnia.

ks. W. Gąsiewski ${ }^{81}$, dziekan prużański

${ }^{80}$ Anniwersarz, rocznica, (z łac. annus vertere) - coroczny, obchód pewnej rocznicy, nabożeństwo w rocznice np. czyjeś śmierci. Anniwersarze czesto na wieczyste czasy fundowane były przy kościołach klasztornych.

${ }^{\text {h }}$ Intrata (łac.) - dochód, zysk.

${ }^{\mathrm{i}}$ Krescencja (łac. crescentia) - dawniej: plony uzyskane w ciągu jednego roku w gospodarstwie rolnym, zbiory, urodzaj.

${ }^{81}$ Ks. Gąsiewski Witalis, ur. ok. 1824, wyświęcony w 1849, miał tytuł kandydata teologii. W latach 1859-1863 był proboszczem parafii pw. Wniebowzięcia NMP w Prużanach, na początku lat 70. XIX wieku był mansjonarzem w Knyszynie, dekanat białostocki. Odznaczony Złotym Krzyżem Zasługi i medalem na pamiątkę wojny krymskiej 1853-1856. 


\section{THE INVENTORY OF THE PARISH CHURCH IN KIWATYCZE OF 1853}

\section{Summary}

The Roman Catholic Parish of Saints Peter and Paul in the borderland village of Kiwatycze, in the district of Prużana (now the Republic of Belarus) dates back to the early sixteenth century. For over four centuries the parish was part of several dioceses. First it was in the Diocese of Lutsk. In 1798, as a result of the Tsarist Russian legislation it was moved to the Diocese of Vilnius. When in 1925 the Diocese of Pinsk came into existence under the edict of Pope Pius XI Vixdum Poloniae unitas, the parish Kiwatycze became part of it. The inventory of the church in Kiwatycze, made due to the fact that the parish was taken over by Rev. Tomasz Lenczewski, after the death of Rev. Mikołaj Bogdanowicz, illustrates the history of the parish church, its interior décor, sacred vessels and vestments, registry books, the state of the parish library, parish presbytery and farm buildings, a landed estate and the population residing in the parish. The facts included in the inventory were consistent with the actual state of the parish, which was confirmed by the signature and stamp of Rev. Witalis Gąsiewski - the Dean of Prużana.

Translated by Aneta Kiper 